\title{
Concentration of trace elements in raw milk from cows in the southeast of Córdoba province, Argentina
}

\author{
Alejo L. Pérez-Carrera ${ }^{1}$ - Flavia E. Arellano ${ }^{1}$. \\ Alicia Fernández-Cirelli ${ }^{1}$
}

Received: 24 November 2015 /Revised: 14 April 2016/Accepted: 15 April 2016 /

Published online: 12 May 2016

(C) INRA and Springer-Verlag France 2016

\begin{abstract}
In recent years, trace elements in cow milk have been considered good bioindicators of pollution in the agricultural environment. The aim of the study was to analyze the correlation between trace element content in livestock drinking water and cow milk from dairy farms located in the southeast of Córdoba province, Argentina. Groundwater is the main source of livestock drinking water. According to the results, trace elements were grouped in three categories: (a) those that were in high concentration in phreatic water and in low concentration in deep wells (As, V); (b) those which showed the opposite trend $(\mathrm{Cu}, \mathrm{Fe}, \mathrm{Mn}, \mathrm{Zn})$; and (c) those that were in very low concentrations in all water samples $(\mathrm{Cd}, \mathrm{Cr}, \mathrm{Ni}, \mathrm{Pb}$, and $\mathrm{Se})$. In elements from group (a), a positive correlation between As content in water and in milk was observed. For elements included in group (b), it was observed a higher concentration in milk samples from farms that use deep wells, related with their higher concentrations in water. $\mathrm{Cr}, \mathrm{Ni}$, $\mathrm{Pb}$, and Se milk contents are within the ranges reported in other areas. Soil and forage trace element content may contribute to their presence in milk. Since information about transference of trace elements from environmental matrices to milk is very scarce, at national and international levels, further studies are necessary, including speciation in milk and dairy products, to guarantee food safety.
\end{abstract}

Keywords Cow milk · Trace elements · Groundwater · Soil and forage

Electronic supplementary material The online version of this article (doi:10.1007/s13594-016-0290-5) contains supplementary material, which is available to authorized users.

Alicia Fernández-Cirelli

afcirelli@fvet.uba.ar

1 Unidad Ejecutora de Investigaciones en Producción Animal (INPA), UBA-CONICET; Centro de Estudios Transdiciplinarios del Agua (CETA), UBA; Facultad de Ciencias Veterinarias, Universidad de Buenos Aires (UBA), Av. Chorroarín No. 280, C1427CWO Buenos Aires, Argentina 


\section{Introduction}

Increased awareness on the influence of diet on human health has prompted to produce food of higher quality, rich in nutrients and health promoters (Ataro et al. 2008).

The analysis of production processes and identification of quality markers for milk and dairy products is of great importance for their evaluation and to assure their safeness. Consequently, as a safeguard, one of the main objectives in livestock production is to undertake a careful and thorough assessment of all mechanisms by which feedstuff quality, manufacturing processes, and environmental conditions, including health parameters, can influence milk properties (Vahčić et al. 2010).

Cow milk and its products are basic foods and constitute an important source of nutrients in human diet. Their content of protein, fat, carbohydrates, vitamins and minerals determine their biological and technological properties.

Although the fundamental composition of cow milk is known, its microelement content is generally unknown. It has been reported that the content of the main mineral components, such as $\mathrm{Ca}, \mathrm{P}, \mathrm{K}, \mathrm{Na}, \mathrm{Mg}, \mathrm{Cl}$, and $\mathrm{S}$, do not vary and undergoes only slight changes depending on the lactation phase and the quality of nutrition, in particular, under the influence of applied mineral additives or environmental conditions, mainly due to chemical pollutants (Dobrzański et al. 2005).

In recent years, there has been a growing interest on microelements, as their presence in food is an indicator of quality, such as processing conditions, environmental pollution, sanitation, and husbandry, and may affect the chemical and functional properties of milk (Ayar et al. 2009). The content of trace elements in cow milk has begun to be more widely studied, particularly in industrialized and polluted regions, since it is considered a good bioindicator of pollution of the agricultural environment (Dobrzański et al. 2005; Elbagermi et al. 2014).

As environmental contaminants, trace metals constitute one of the greatest dangers to human health because they tend to be stable; they persist in the environment and are accumulated in the food chain. To analyze their toxicological aspects, it is necessary to know its concentration in diet, their oxidation state, and chemical form, as well as the quantity of other components that influence their absorption and metabolism (Hughes et al. 2011).

Generally, animals reduce human exposure to trace metals; for instance, levels present in different environmental matrices are higher than those found in food. However, some trace elements have been found in cattle diet at levels tolerated by the animals that could be transferred to their tissues at concentrations not acceptable for human consumption. The elements identified are $\mathrm{As}, \mathrm{Cd}, \mathrm{Cr}, \mathrm{Cu}, \mathrm{Pb}$, and $\mathrm{Se}$ (NRC 2005; Ayar et al. 2009).

In the case of arsenic (As), its presence in drinking water is one of the most important health problems in the world. Arsenic is a broadly distributed element in the nature and is of high toxicity for living organisms. The Chacopampean plain of central Argentina constitutes one of the largest regions of high As levels in groundwater known. One of the most affected areas is the southeast of Córdoba. In previous studies carried out in this area, groundwater As concentrations were above the recommended limit for livestock drinking water (Pérez-Carrera et al. 2008). This fact motivated a study to estimate an As biotransference factor to milk 
considering drinking water as the main source of this metalloid (Pérez-Carrera and Fernández-Cirelli 2005; 2008).

The aim of the present work was to analyze the relationship between trace elements content in drinking water and in cow milk from dairy farms located in the southeast of Córdoba province, one of the most important dairy areas of Argentina. These studies may contribute to the knowledge of the influence of livestock drinking water on milk composition regarding elements of toxicological and/or nutritional importance.

\section{Materials and methods}

\subsection{Study area}

The study area is located in the southeast of Córdoba province, Argentina, between $62^{\circ}$ $33^{\prime}$ and $62^{\circ} 57^{\prime}$, west longitude and $32^{\circ} 12^{\prime}$ and $32^{\circ} 50^{\prime}$, south latitude, in the rural area belonging to four counties: Bell Ville, Morrison, Cintra, and San Antonio de Litín (Fig. 1). Water, soil, forage, and milk were taken from 30 small (10-20 animals) and medium (100-120 animals) dairy farms.

\subsection{Sampling and samples preparation}

\subsubsection{Water}

Water samples $(500 \mathrm{~mL})$ were collected in polyethylene bottles rinsed with $10 \%$ nitric acid and deionized water prior to collection. Samples were cooled (but not frozen) for

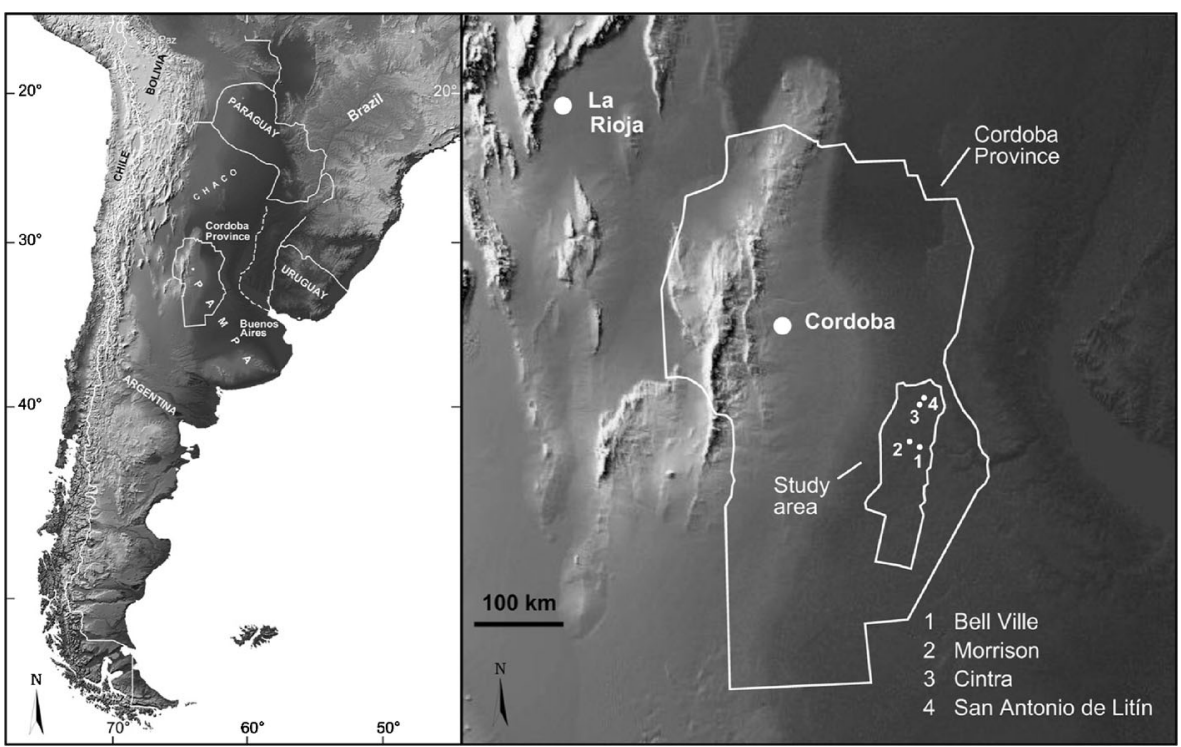

Fig. 1 Maps of Córdoba province in Argentina (left) and of the study area (right) in the southeast of Córdoba

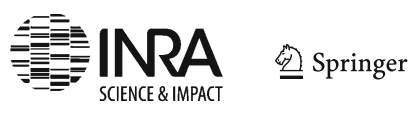


their transportation to the laboratory (APHA 1993). All measurements were performed in duplicate with relative errors below $1.0 \%$.

\subsubsection{Milk}

Raw milk samples $(500 \mathrm{~mL})$ from three animals were collected at each small farm while five animals were chosen at each medium-sized farm. The animals were randomly selected. Samples were placed into polyethylene bottles that were rinsed with $10 \%$ nitric acid in deionized water prior to collection. Samples were cooled (but not frozen) for their transportation to the laboratory. Milk samples (approximately $100 \mathrm{~g}$ from each) were placed into 400-mL heat-resistant glass beakers and dryly reduced to ash as previously described by Cervera et al. (1994) and Pérez-Carrera and FernándezCirelli (2005). White ash was moistened with a reagent grade water, dissolved in $10 \mathrm{~mL}$ $6 \mathrm{M} \mathrm{HCl}$, filtered through Whatman No. 1 paper into a $25-\mathrm{mL}$ volumetric flask, and diluted to original volume with $6 \mathrm{M} \mathrm{HCl}$. Duplicate controls were prepared by treating the ash solution with the same digestion procedure.

\subsubsection{Soil}

Soil samples were air dried, sieved through a 2-mm sieve mesh, and pulverized in an agate mortar. For trace element content determination, $0.1 \mathrm{~g}$ of soil were subjected to acid digestion with $10 \mathrm{~mL}$ of $\mathrm{HNO}_{3}$ (c) and $10 \mathrm{~mL}$ of $\mathrm{H}_{2} \mathrm{SO}_{4}$ (c). After the complete oxidation of organic matter, and production of sulfur trioxide fumes, the samples were cooled and diluted to $50 \mathrm{~mL}$ with deionized water.

\subsubsection{Forage}

All forage samples were washed with $\mathrm{H}_{2} \mathrm{O}_{\mathrm{d}}$ and ultrapure water to removed soil particles. The disintegration of the vegetable samples was performed by microwave digestion in closed cup. The following scheme digestion was performed: $10 \mathrm{~mL} \mathrm{HNO}_{3}$ and $1 \mathrm{~mL} \mathrm{H}_{2} \mathrm{O}_{2}$ per $0.5 \mathrm{~g}$ forage sample. There were 2 cycles, $2 \mathrm{~min}$ at $250 \mathrm{~W}$ and $5 \mathrm{~min}$ at $750 \mathrm{~W}$. The samples were diluted to $50 \mathrm{~mL}$ with deionized water.

\subsection{Reagents}

All reagents were of analytical grade. Working solutions were prepared by appropriate serial dilution of commercially available multielement standard stock solutions (PerkinElmer. Atomic Spectroscopy Standard No. 9300281) using ultrapure water provided by a Milli-Q water purification System (Millipore, Bedford, MA, USA).

Certified reference materials for verification of the calibration procedure and validation of the analytical method were used for each type of studied matrices. In the case of water, TM 26.2, TMDA 51.2, TMDA 52.2, and TMDA 54.3 from the National Water Research Institute of Canada (NWRI) were used. In the case of soils, WQB CRM-3 were used (NWRI). For forage, NIST-1570a was used, from the National Institute of Standards and Methods (NIST), and, in the case of milk, NIST-8435 was used. 
To avoid possible matrix interference internal standard technique was used. This technique was performed using Yttrium $\left(1 \mathrm{mg} . \mathrm{L}^{-1}\right)$ as internal standard according to Milburn, 1996.

\subsection{Trace elements analysis}

Trace elements content in water, milk, soil, and forage was determined by inductively coupled plasma optical emission spectrometry (ICP-OES, PerkinElmer, Optima 2000) following standardized methods (APHA 1993). Determinations were performed in duplicate being the relative error $<1.0 \%$ for all of them. In the case of As, due to its generally low concentrations in cow milk, it was used as a highly sensitive hydride generator coupled to ICP-OES (PerkinElmer 1979) for its determination in collected milk samples following the procedure previously described by Cervera et al. (1994). All samples were analyzed in duplicate with a relative error below $1.0 \%$.

\subsection{Statistical analysis}

The average, standard deviation, and minimum and maximum of trace elements concentrations in milk samples from dairy farms using phreatic water or deep wells for drinking water were calculated using the statistical package Statistica for Windows (ver. 5.1, 1997, Statsoft, USA).

To compare and validate the concentration of trace elements founded with the certificated values, an accuracy test was used. This test was based on the calculation of the recovery percentage (trueness). The results are showed in Supplementary Tables SI and SII. For those elements which values were not determinate in certified reference, it was used the internal standard using yttrium $\left(1 \mathrm{mg} . \mathrm{L}^{-1}\right)$ previously described in Section 2.3. Certified concentrations of As, Cd, Cr, Ni, and $\mathrm{V}$ for milk (NIST-8435); $\mathrm{Cd}, \mathrm{Cr}, \mathrm{Cu}, \mathrm{Pb}$, and $\mathrm{V}$ in soil (WQB CRM-3); and $\mathrm{Cr}, \mathrm{Fe}$, and $\mathrm{Pb}$ in forage (NIST-1570a) were not determined since reference materials were not available, therefore those data should be considered as preliminary.

\section{Results}

In the studied area, groundwater is the main source of livestock drinking water. Phreatic water wells account for $60 \%$ of the analyzed samples. The majority of phreatic water wells were found between 3- and 8-m depth, with extremes of 2- and 15-m depth. The remaining $40 \%$ of wells ranged in depth from around 80 - to $150-\mathrm{m}$ depth (deep wells).

Trace element content in cow's drinking water is shown in Tables 1 and 2. According to these results, trace elements may be grouped in three categories: (a) those that are in high concentration in phreatic water and in low concentration in deep wells (As, V); (b) those which show the opposite trend $(\mathrm{Cu}, \mathrm{Fe}$, $\mathrm{Mn}, \mathrm{Zn}$ ); and (c) those that are in very low concentrations in all water samples from the study area $(\mathrm{Cd}, \mathrm{Cr}, \mathrm{Ni}, \mathrm{Pb}$, and $\mathrm{Se})$.

In previous studies, correlations between As content both in phreatic water and deep wells, and its content in milk allowed us to calculate a biotransference factor to milk (Pérez-Carrera and Fernández-Cirelli 2005). Taking into account those results, we have 
Table 1 Trace elements concentrations $\left(\mu \mathrm{g} . \mathrm{L}^{-1}\right)$ in samples obtained from phreatic water

\begin{tabular}{llllll}
\hline & Maximum & Minimum & Average & Standard deviation & $\mathrm{NRC}^{\dagger}$ \\
\hline $\mathrm{As}$ & 4550 & 71 & 1282 & 1430 & 50 \\
$\mathrm{Cd}$ & $<0.5^{\ddagger}$ & $<0.5^{\ddagger}$ & - & - & 5 \\
$\mathrm{Cr}$ & $<5^{\ddagger}$ & $<5^{\ddagger}$ & - & - & 100 \\
$\mathrm{Cu}$ & 22.4 & $<4$ & $6.2^{\S}$ & $6.8^{\S}$ & 1000 \\
$\mathrm{Fe}$ & 1405 & $<5$ & $154^{\S}$ & $415.3^{\S}$ & 2000 \\
$\mathrm{Mn}$ & 175.4 & $<2$ & $28.1^{\S}$ & $55.3^{\S}$ & 50 \\
$\mathrm{Ni}$ & $<3^{\star}$ & $<3^{\ddagger}$ & - & - & 250 \\
$\mathrm{~Pb}$ & $<12^{\ddagger}$ & $<12^{\star}$ & - & - & 15 \\
$\mathrm{Se}$ & $<5^{\ddagger}$ & $<5^{\ddagger}$ & - & - & - \\
$\mathrm{V}$ & 5661.4 & 125.2 & 2079.5 & 1891 & 100 \\
$\mathrm{Zn}$ & 129.8 & 25.8 & 64 & 28.2 & 5000 \\
\hline
\end{tabular}

${ }^{\dagger}$ Guideline level $\left(\mu \mathrm{g} . \mathrm{L}^{-1}\right.$ ) for dairy cattle drinking water (NRC 2005)

* Detection limit

$\S$ To calculate the average and standard deviation it was considered half the value of the detection limit

analyzed milk from dairy farms that used phreatic water and deep wells to study their composition and trace elements content.

In reference to Vanadium (V) content, all of the samples from phreatic water were above the guideline level recommended for cattle drinking water, while $8 \%$ of the samples from deep wells are above that value. All the other trace elements were below the recommended values both in phreatic water and deep wells.

Table 2 Trace elements concentrations $\left(\mu \mathrm{g} . \mathrm{L}^{-1}\right)$ in samples obtained from deep wells

\begin{tabular}{llllll}
\hline & Maximum & Minimum & Average & Standard deviation & $\mathrm{NRC}^{\dagger}$ \\
\hline $\mathrm{As}$ & 79 & 29 & 56 & 16 & 50 \\
$\mathrm{Cd}$ & $<0.5^{\ddagger}$ & $<0.5^{\ddagger}$ & - & - & 5 \\
$\mathrm{Cr}$ & $<5^{\ddagger}$ & $<5^{\ddagger}$ & - & - & 100 \\
$\mathrm{Cu}$ & 46.1 & $<4$ & $7.7^{\S}$ & $12.7^{\S}$ & 1000 \\
$\mathrm{Fe}$ & 3982.4 & 14.7 & 865.9 & 1291.4 & 2000 \\
$\mathrm{Mn}$ & 684.6 & 25.1 & 232.1 & 209.6 & 50 \\
$\mathrm{Ni}$ & $<3^{\ddagger}$ & $<3^{\ddagger}$ & - & - & 250 \\
$\mathrm{~Pb}$ & $<12^{\ddagger}$ & $<12^{\ddagger}$ & - & - & 15 \\
$\mathrm{Se}$ & $<5^{\ddagger}$ & $<5^{\ddagger}$ & - & - & - \\
$\mathrm{V}$ & 274.5 & $<4$ & $26.3^{\S}$ & $78.2^{\S}$ & 100 \\
$\mathrm{Zn}$ & 513.9 & 16.2 & 157.3 & 150.9 & 5000 \\
\hline
\end{tabular}

${ }^{\dagger}$ Guideline level ( $\left.\mu \mathrm{g} . \mathrm{L}^{-1}\right)$ for dairy cattle drinking water (NRC 2005)

* Detection limit

$\S$ To calculate the average and standard deviation it was considered half the value of the detection limit 
The mineral content of milk is about $0.7 \%$ of its dry matter. This fraction has a high nutritional and technological importance, in particular, the contribution of $\mathrm{Ca}$ and $\mathrm{P}$. In raw milk, approximately $65 \%$ of $\mathrm{Ca}, 60 \%$ of $\mathrm{Mg}$, and $50 \%$ of $\mathrm{P}$ are associated with casein, while $\mathrm{Na}$ and $\mathrm{K}$ are in solution (DeGaris and Lean 2008). The results of the analysis of major elements in raw milk samples are shown in Table 3.

The concentrations of trace elements in milk samples are summarized in Table 4, corresponding to dairy farms using phreatic water (A) or deep wells (B), respectively.

Regarding elements included in group (b), $\mathrm{Cu}, \mathrm{Fe}$, and $\mathrm{Mn}$ concentrations in milk samples from dairy farms using water from deep wells were between the ranges determinate in milk samples from dairy farms using phreatic water. In the case of $\mathrm{Zn}$ concentration, there were higher values obtained in milk samples from dairy farms using deep wells. No significant differences were found (ANOVA, Kruskal-Wallis).

In Table 5, the concentrations of the different trace elements determined in this work are compared with that obtained by other authors.

Since trace elements are present in milk, although in low concentrations, but are at non detectable or detectable in very low levels both in phreatic water and in deep wells, soil, and forage in the studied dairy farms were analyzed for trace elements.

Soil content of $\mathrm{Cd}\left(<0.5\right.$ to $\left.28 \mathrm{mg} \cdot \mathrm{kg}^{-1}\right), \mathrm{Cr}$ (42.8 to $\left.108.2 \mathrm{mg} \cdot \mathrm{kg}^{-1}\right), \mathrm{Cu}$ (31.5 to $\left.93 \mathrm{mg} \cdot \mathrm{kg}^{-1}\right), \mathrm{Pb}\left(7.8\right.$ to $\left.55 \mathrm{mg} \cdot \mathrm{kg}^{-1}\right)$, Se $\left(<0.1\right.$ to $\left.0.8 \mathrm{mg} \cdot \mathrm{kg}^{-1}\right)$ and $\mathrm{Zn}$ (61 to $\left.129.5 \mathrm{mg} \cdot \mathrm{kg}^{-1}\right)$ were in the range reported for non contaminated agricultural soil in a few countries around the world (Kabata-Pendias and Mukherjee 2007).

In alfalfa, concentrations of $\mathrm{Cd}$ were below the detection limit of the method, and $\mathrm{Cu}$ (8.2 to $15.2 \mu \mathrm{g} \cdot \mathrm{kg}^{-1}$ ) was below the phytotoxicity level (de Souza Silva et al. 2014). Zinc concentrations $\left(20.2\right.$ to $\left.56.8 \mu \mathrm{g} . \mathrm{g}^{-1}\right)$ were in the range reported in literature (Rafique et al. 2006).

$\mathrm{Pb}$ levels in soil and alfalfa ( $<1.0$ to $8.3 \mu \mathrm{g} \cdot \mathrm{g}^{-1}$ ) are low due to the lack of industrial pollution in the study area. Since Se levels were low in the studied soil, the concentrations in forage were below the detection limit.

\section{Discussion}

According to the results obtained in groundwater samples, the trace elements could be grouped in three groups, previously described, (a) As and V that appears in high concentrations in phreatic water samples; (b) $\mathrm{Cu}, \mathrm{Fe}, \mathrm{Mn}$, and $\mathrm{Zn}$ present in high concentrations in deep wells; and (c) those elements that are in low concentrations in all samples.

Considering As concentration, all the samples from phreatic water and $80 \%$ of deep wells were above the level of $50 \mu \mathrm{g} . \mathrm{L}^{-1}$ proposed by the National Research Council for cow's drinking water (NRC 2005). Vanadium (V) usually occurs together with As and $\mathrm{F}$ in groundwater in extensive areas of Argentina. Its importance in the animal nutrition has not been demonstrated yet (Pérez-Carrera et al. 2015).

The obtained results are comparable with those reported by Taverna et al. (2001), in raw milk from dairy farms from another milk basin located at the east of our study area. The average concentration of $\mathrm{Ca}, \mathrm{P}, \mathrm{K}$, and $\mathrm{Mg}$ were within the range considered appropriate for dairy cattle. These results confirm the assessment previously reported by Dobrzański et al. (2005) that the content of main mineral 
Table 3 Macromineral concentration in analyzed milk samples (g.kg $\left.{ }^{-1}\right)$

\begin{tabular}{lllll}
\hline Element & Minimum & Maximum & Average & SD \\
\hline $\mathrm{Ca}$ & 0.7 & 1.6 & 1.03 & 0.26 \\
$\mathrm{P}$ & 0.9 & 1.3 & 1.06 & 0.12 \\
$\mathrm{Na}$ & 0.3 & 1.2 & 0.6 & 0.25 \\
$\mathrm{~K}$ & 1.0 & 2.7 & 1.5 & 0.36 \\
$\mathrm{Mg}$ & 0.06 & 0.2 & 0.09 & 0.03 \\
\hline
\end{tabular}

components is not diverse and may undergo only slight changes in different breeding and environmental conditions.

As expected, higher As concentrations were determined in milk samples from dairy farms using the phreatic water than the ones from those using deep wells. Although $\mathrm{V}$ is related to As due to their common origin in water, it shows a distinctive behavior regarding its possible transference to milk. In spite of its high concentration in water, $\mathrm{V}$ presence in milk samples could be determined only in $23 \%$ of the analyzed samples from dairy farms using phreatic water. In addition, none of the analyzed milk samples from dairy farms using deep wells were above the detection limit from $\mathrm{V}$.

Copper $(\mathrm{Cu})$ is a cofactor of many cuproenzymes and several proteins are involved in its metabolism (Miranda et al. 2009). Cu concentration in bovine milk reported in the literature is very variable (Table 5). In the analyzed samples at this work, $\mathrm{Cu}$ concentration was within the reported values in literature.

Table 4 Trace element concentrations in milk (ng. $\mathrm{g}^{-1}$ ) from dairy farms that use drinking water obtained from the phreatic aquifer (A) and from deep wells (B)

\begin{tabular}{lllllll}
\hline & $\mathrm{A}$ & \multicolumn{5}{c}{ B } \\
\hline Elements & Minimum & Maximum & Mean $\pm \mathrm{SD}^{\star}$ & Minimum & Maximum & Mean $\pm \mathrm{SD}^{\ddagger}$ \\
$\mathrm{As}$ & 0.7 & 11 & $4 \pm 2.8$ & 0.2 & 7.8 & $3.5 \pm 2$ \\
$\mathrm{Cr}$ & $<3.5^{\dagger}$ & 72.8 & $38 \pm 20.6^{\ddagger}$ & 33 & 64.7 & $54 \pm 9$ \\
$\mathrm{Cu}$ & 9 & 90 & $26.2 \pm 20.5$ & 10 & 68 & $38.5 \pm 19.5$ \\
$\mathrm{Fe}$ & 245 & 3297 & $855.3 \pm 737$ & 364 & 2790 & $966 \pm 734$ \\
$\mathrm{Mn}$ & 5.2 & 95 & $21 \pm 18$ & 11 & 87 & $29 \pm 22$ \\
$\mathrm{Ni}$ & 22 & 149.6 & $48 \pm 25$ & 29.2 & 93.5 & $48.3 \pm 16.4$ \\
$\mathrm{~Pb}$ & $<5^{\dagger}$ & 51 & $23 \pm 13^{\ddagger}$ & $<5^{\dagger}$ & 64 & $24 \pm 17.3^{*}$ \\
$\mathrm{Se}$ & $<5^{\dagger}$ & 13.6 & $5.3 \pm 3.8^{*}$ & $<5^{\dagger}$ & 18 & $9.4 \pm 5.1^{*}$ \\
$\mathrm{~V}$ & $<2^{\dagger}$ & 8.9 & $2.5 \pm 2.2^{\star}$ & $<2^{\dagger}$ & - & - \\
$\mathrm{Zn}$ & 300 & 2900 & $1800 \pm 800$ & 510 & 3995 & $2300 \pm 1360$ \\
\hline
\end{tabular}

$\dagger$ Detection limit of the methodology

* To calculate the mean and standard deviation it was considered half the value of the detection limit 
Iron $(\mathrm{Fe})$ content in milk samples are comparable to the values reported in raw milk by Arellano et al. (2014) and within the range reported for pasteurized milk (Soares et al. 2010). The average level of $\mathrm{Fe}$ is higher than the average value reported in other studies by Rodríguez-Rodríguez et al. (2001) and NRC (2005), Table 5. These results indicate that high Fe content in drinking water and food, as it has been determined in this work, may affect Fe milk content.

Manganese (Mn) is a cofactor of mutase antioxidant enzyme and its elevated content could reduce Fe absorption. The average level of $\mathrm{Mn}$ found in this study is an order of magnitude lower that the reported in the literature (Table 5) and show differences between dairy farms using phreatic water and those using deep wells, although they are not statistically significant.

The average content of zinc $(\mathrm{Zn})$ in milk (Tables 4$)$ was lower than it was previously reported (Table 5). Zn deficiency reduces the immune response and the integrity of epithelia. It has been shown that $\mathrm{Zn}$ supplementation reduces the number of somatic cells in bovine milk (Pechová et al.. 2006). The study area is one of the most important dairy areas in Argentina, where $27.5 \%$ of milk production is characterized by less than 100,000 CFU.mL ${ }^{-1}$; however, the concentration of somatic cells was greater than 400,000 cells. $\mathrm{mL}^{-1}$ (data not shown), which could be associated with $\mathrm{Zn}$ deficiency.

Among those elements which were in very low concentration in water samples, group (c), Cd was not detected in any of the milk samples (detection limit: 3 ng.g ${ }^{-1}$ ).

Chromium (Cr) plays a crucial role in glucose metabolism, in which it enhances insulin activity (NRC 2005; Miranda et al.. 2009). The content of Cr in milk samples is within the range reported by Licata et al. (2004) and Soares et al. (2010) in a dairy area in Calabria, Italy (Table 5). However, the main concentrations of $\mathrm{Cr}$ in milk samples were lower than those previously reported by Ataro et al. (2008).

The content of $\mathrm{Ni}$ in milk samples was, in all cases, below the range reported by Coni et al. (1994, 1995) in Italy, and that reported for pasteurized milk in Brazil by Soares et al. (2010), Table 5.

The concentrations of Se in milk samples (Table 4), are within the range reported in bovine milk by other authors (Licata et al. 2004; Dobrzański et al. 2005) and lower than that reported by Ayar et al. (2009)

Lead $(\mathrm{Pb})$ concentrations are in accordance with the reported values in non contaminated areas around the world (Ataro et al. 2008; Patra et al. 2008; Ayar et al. 2009). These results relate to the fact that concentrations of this element in water and forage in this area are below the limit considered safe for ruminants. Contrariwise, milk $\mathrm{Pb}$ concentrations reported by Soares et al. (2010) in industrial polluted areas are higher (mean: 230 ng.g ${ }^{-1}$ ).

Arsenic levels in soil (2.1 to $\left.8.2 \mathrm{mg} \cdot \mathrm{kg}^{-1}\right)$ are in accordance with the concentrations reported in non contaminated areas (Nriagu et al. 2007; Kabata-Pendias and Mukherjee 2007). In alfalfa (Medicago sativa) leaves, the most often used forage in the area, As levels ranged between 0.1 and $1.5 \mu \mathrm{g} . \mathrm{g}^{-1}$. No reference values were found for comparison, but they are below the ranges reported by Bundschuh et al. (2012) on the leaves used for livestock fodder in México.

The low levels of $\mathrm{Pb}$ and $\mathrm{Se}$ determined in soil and forage may suggest the existence of another source for these elements to explain their occurrence in milk, which requires further studies. 
Table 5 Microelements and trace elements concentrations in milk (ng.g ${ }^{-1}$ ) from groups (a)-(c) compared with other works

\begin{tabular}{|c|c|c|c|}
\hline \multirow[t]{2}{*}{ Trace element } & \multicolumn{2}{|l|}{ Concentration } & \multirow[t]{2}{*}{ Reference } \\
\hline & Min-max & Mean & \\
\hline \multicolumn{4}{|l|}{ Group (a) } \\
\hline \multirow[t]{3}{*}{ As } & $14-57$ & - & Dobrzański et al. 2005 \\
\hline & $<0.2-80$ & 20 & Ayar et al. 2009 \\
\hline & $0.2-11$ & 4 & This work \\
\hline \multirow[t]{3}{*}{$\mathrm{V}$} & $44.1-151.2$ & - & Dobrzański et al., 2005 \\
\hline & $23.4-42$ & - & Ataro et al. 2008 \\
\hline & $<2-8.9$ & 2.5 & This work \\
\hline \multicolumn{4}{|l|}{ Group (b) } \\
\hline \multirow[t]{4}{*}{$\mathrm{Cu}$} & $<0.13-737.6$ & 2 & Licata et al. 2004 \\
\hline & $7.2-357.8$ & 51.8 & Sola-Larrañaga and Navarro-Blasco 2009 \\
\hline & $100-2550$ & 1730 & Soares et al. 2010 \\
\hline & $9-90$ & 20.5 & This work \\
\hline \multirow[t]{3}{*}{$\mathrm{Fe}$} & $196-1030$ & 500 & Rodríguez-Rodríguez et al. 2001 \\
\hline & $1457-2321$ & 1859 & Arellano et al. 2014 \\
\hline & $245-3297$ & 855.3 & This work \\
\hline \multirow[t]{3}{*}{$\mathrm{Mn}$} & $14-614$ & 231 & Coni et al. 1994 and 1995 \\
\hline & $130-221$ & 169 & Arellano et al 2014 \\
\hline & $5.2-95$ & 25 & This work \\
\hline \multirow[t]{4}{*}{$\mathrm{Zn}$} & $2370-6800$ & 4540 & Rodríguez-Rodríguez et al. 2001 \\
\hline & $3564-8229$ & 6150 & Brodziak et al. 2011 \\
\hline & $27,140-42,870$ & 34,330 & Arellano et al. 2014 \\
\hline & $300-3995$ & 2050 & This work \\
\hline \multicolumn{4}{|l|}{ Group (c) } \\
\hline \multirow[t]{4}{*}{$\mathrm{Cr}$} & $<1.5-82$ & - & Licata et al. 2004 \\
\hline & $186-371$ & - & Ataro et al. 2008 \\
\hline & $3-179$ & 79 & Soares et al. 2010 \\
\hline & $<3.5-72.8$ & 38 & This work \\
\hline \multirow[t]{3}{*}{$\mathrm{Ni}$} & $162-712$ & - & Coni et al. 1994 and 1995 \\
\hline & $2-210$ & 73 & Soares et al. 2010 \\
\hline & $22-149.6$ & 48 & This work \\
\hline \multirow[t]{3}{*}{$\mathrm{Pb}$} & $<0.14-19.7$ & - & Ataro et al. 2008 \\
\hline & $90-110$ & 103 & Ayar et al. 2009 \\
\hline & $<5-64$ & 23 & This work \\
\hline \multirow[t]{3}{*}{$\mathrm{Se}$} & $11.7-53.4$ & - & Dobrzański et al. 2005 \\
\hline & $230-350$ & 232 & Ayar et al. 2009 \\
\hline & $<5-18$ & 5.3 & This work \\
\hline
\end{tabular}




\section{Conclusions}

Taking into account the data obtained in this work and considering it from a toxicological point of view, trace elements content in milk samples are similar to those reported in non contaminated areas and seemingly do not represent a risk for human health.

A correlation between drinking water and milk As content was observed. A similar trend may be seen for $\mathrm{Fe}, \mathrm{Cu}, \mathrm{Mn}$, and $\mathrm{Zn}$. These last elements are also present in animal food (mainly forage), which make an important contribution to their milk content, whereas in the former case, water is by far the main source of As in milk.

According to our results, there is no transference of $\mathrm{V}$ from drinking water to cow milk. Soil and forage trace elements content may contribute to their presence in milk. Nevertheless, concentrations determined in the present study are within the range reported for non polluted areas.

Since information about transference of trace elements from environmental matrices to milk is very scarce, not only at a national but at an international level, further studies on this subject are necessary, including speciation in milk and dairy products, to guarantee food safety.

Acknowledgments Authors are indebted to the University of Buenos Aires and to CONICET (National Research Council) for financial support.

\section{Compliance with ethical standards}

Conflict of interest The authors on this manuscript, Alejo L. Peréz Carrera, Ph.D.; Mrs Flavia E. Arellano; and Alicia Fernández Cirelli declare that they have no conflict of interest.

Statement of human and animal rights This article does not contain any studies with human or animals subjects performed by any of the authors.

\section{References}

APHA (1993) Standard methods for the examination of water and wastes. American Public Health Association, Washington DC

Arellano FE, Alvarez Gon alvez CV, Pérez-Carrera AL, Calzetta Resio AN, Fernádez Cirelli A (2014) Presencia de Elementos Traza Inorgánicos de Importancia Nutricional en Leche de Rumiantes. SNS, Revista Senasa 5-6:1-8

Ataro A, McCrindle RI, Botha BM, McCrindle CME, Ndibewu PP (2008) Quantification of trace elements in raw cow's milk by inductively coupled plasma mass spectrometry (ICP-MS). Food Chem 111:243-248

Ayar A, Sert D, Akın N (2009) The trace metal levels in milk and dairy products consumed in middle Anatolia-Turkey. Environ Monit Assess 152:1-12

Brodziak A, Litwińczuk A, Kędzierska-Matysek M, Król J (2011) Content of selected macro- and microelements in milk of different cows breeds and rennet whey. Ochrona Środowiska i Zasobów Naturalnych 48:467-474

Bundschuh J, Nath B, Bhattacharya P, Liu CW, Armienta MA, Lopez MVM, Tenuta Filho A (2012) Arsenic in the human food chain: the Latin American perspective. Sci Total Environ 429:92-106

Cervera M, Lopez J, Montoro R (1994) Arsenic content of Spanish cows' milk determined by dry ashing hydride generation atomic absorption spectrometry. J Dairy Res 61:83-89 
Coni E, Caroli S, Ianni D, Bocca A (1994) A methodological approach to the assessment of trace elements in milk and dairy products. Food Chem 50:203-210

Coni E, Bocca A, Ianni D, Caroli S (1995) Preliminary evaluation of the factors influencing the trace element content of milk and dairy products. Food Chem 52:123-130

de Souza Silva ML, Vitti GC,Trevizam AR (2014) Heavy metal toxicity in rice and soybean plants cultivated in contaminated soil. Soil Science And Plant Nutrition. Rev.Ceres vol.61 no.2 http://dx.doi.org/10.1590/ S0034737X2014000200013

DeGaris PJ, Lean IJ (2008) Milk fever in dairy cows: a review of pathophysiology and control principles. Vet J 176(1):58-69

Dobrzański Z, Kolacz R, Górecka H, Chojnacka K, Bartkowiak A (2005) The content of microelements and trace elements in raw milk from cows in the Silesian Region. Pol J Environ Stud 14:685-689

Elbagermi MA, Alajtal AI, Edwards HGM (2014) A comparative study on the physicochemical parameters and trace elements in raw milk samples collected from Misurata-Libya. Sop Transactions on Analytical Chemistry. 1 (2): 15-23. doi:10.15764/ache.2014.02002

Hughes MF, Beck BD, Chen Y, Lewis AS, Thomas DJ (2011) Arsenic exposure and toxicology: a historical perspective. Tox Sci 123(2):305-332. doi:10.1093/toxsci/kfr184

Kabata-Pendias A, Mukherjee AB (2007) Trace elements from soil to human. Springer Science \& Business Media. pp. 9-38.

Licata P, Trombetta D, Cristiani M, Giofré F, Martino D, Caló M, Naccari F (2004) Levels of "toxic" and "essential" metals in simples of bovine milk from various dairy farms in Calabria. Italy Environ Int 30:1-6

Miranda M, Benedito JL, Blanco-Penedo I, López-Lamas C, Merino A, López-Alonso M (2009) Metal accumulation in cattle raised in a serpentine-soil area: relationship between metal concentrations in soil, forage and animal tissues. J Trace Elem Med Bio 23:231-238

Nriagu JO, Bhattacharya P, Mukherjee AB, Bundschuh J, Zevenhoven R, Loeppert RH (2007) Arsenic in soil and groundwater: an overview. Trace Metals and other Contaminants in the Environment 9:3-60

Patra RC, Swarup D, Kumar P, Nandi D, Naresh R, Ali SL (2008) Milk trace elements in lactating cows environmentally exposed to higher level of lead and cadmium around different industrial units. Sci Total Environ 404:36-43

Pechová A, Pavlata L, Lokajová E (2006) Zinc supplementation and somatic cells count in milk of dairy cows. Acta Vet Brno 75:355-361

Pérez-Carrera A, Fernández-Cirelli A (2005) Arsenic concentration in water and bovine milk in Cordoba. Argentina Preliminary results J Dairy Res 72:122-124

Pérez-Carrera A, Moscuzza C, Fernández-Cirelli A (2008) Transfer of arsenic from contaminated dairy cattle drinking water to milk (Córdoba, Argentina). In: Bundschuh J, Armienta MA, Bhattacharya P, Matschullat J, Mukherjee AB (eds) Natural arsenic in groundwaters of Latin America. Arsenic in the environment. Taylor \& Francis/Balkema, Leiden, The Netherlands, pp 419-425

Pérez-Carrera AL, Álvarez Gonçalvez CV, Fernández Cirelli A (2015) Vanadio en agua de bebida animal de tambos del sudeste de Córdoba, Argentina. Revista InVet. 16 (1-2).

Rafique E, Rashid A, Ryan J, Bhatti AU (2006) Zinc deficiency in rainfed wheat in Pakistan: magnitude, spatial variability, management, and plant analysis diagnostic norms. Commun Soil Sci Plant Anal 37(1-2):181-197

NRC -National Research Council (2005) Mineral tolerance of animals (2nd ed.). Committee on minerals and toxic substances in diets and water for animals. Washington, DC: National Academies Press.

Rodríguez-Rodríguez E, Sanz-Alaejos M, Díaz Romero C (2001) Mineral concentrations in cow's milk from the Canary Island. J Food Composition and Analysis 14:419-430

Soares VA, Kus MM, Peixoto AL, Carrocci JS, Salazar RF, Izário-Filho HJ (2010) Determination of nutritional and toxic elements in pasteurized bovine milk from Vale do Paraiba region (Brazil). Food Control 21:45-49

Sola-Larrañaga C, Navarro-Blasco I (2009) Chemometric analysis of minerals and trace elements in raw cow milk from the community of Navarra. Spain Food Chem 112:189-196

Taverna MA, Chávez M, Gagiotti M, Cuatrin A, Charlón V, Negri L, Páez B (2001) Composición mineral de la leche producida en la cuenca lechera central de la Argentina. Revista Argentina de Producción Animal 21:273-274

Vahčić N, Hruškar M, Marković K, Banović M, Colić Barić I (2010) Essential minerals in milk and their daily intake through milk consumption. Mljekarstvo 60:77-85 